\title{
Arcybiskupowi Józefowi Życińskiemu - in memoriam
}

Upłynęło już pięć lat od przedwczesnej i niespodziewanej śmierci Arcybiskupa Józefa Życińskiego, Metropolity Lubelskiego.

W miarę upływu czasu czujemy coraz bardziej i bardziej, kogo straciliśmy - Człowieka, Kapłana, Uczonego i Patriotę w najlepszym rozumieniu tego słowa - zatroskanego o los naszej Ojczyzny, poszukującego niestrudzenie sensu tego świata. Arcybiskup sens ten opierał na wierze w Boga, modlitwie, nauce oraz unikaniu irracjonalizmu, albowiem bez tego odniesienia i dbałości o niezbędną ,estetykę wnętrza człowiek może być skazany do wejścia z powrotem do jaskini, w której wszystko ujdzie i wszystko jest dozwolone".

Jego brak jest odczuwalny jako puste miejsce, stąd pragniemy je choć w części zapełnić, organizując ogólnopolską konferencję naukową pt. Media - Kultura - Dialog - jemu poświęconą, po to, aby spłacić dług duchowy i intelektualny, jaki wszyscy zaciągnęliśmy u niego. My, tj. Kościół Jezusa Chrystusa rozumiany przez papieża Franciszka nie jako 
„urząd celny”, lecz „polowy szpital”, i ludzie dobrej woli, mamy być wspólnotą otwartą na wyzwania naszych czasów.

Uniwersytet Jagielloński, Uniwersytet Papieski Jana Pawła II, Akademia Ignatianum oraz Adwokatura Polska, której posłannictwo „Polsce - Wierność, Praw i Wolności Obrona, Potrzebującym - Pomoc" było mu bliskie, starają się sprostać takiemu pojmowaniu Kościoła i naukowemu opisowi świata, któremu od zawsze był wierny Arcybiskup Józef.

Arcybiskupa, który czynnie angażował się w obrony polityczne w stanie wojennym, łączyła z Adwokaturą serdeczna więź, oparta na tym samym systemie wartości, trosce o człowieka i jego niezbywalne prawa. Jej wyrazem jest nie tylko wyróżnienie przyznane mu z prawdziwą radością przez Naczelną Radę Adwokacką - „Adwokatura zasłużonym", które zechciał przyjąć, lecz także sześciopłytowy album zawierający jego homilie i wykłady wraz z muzyką organową, stanowiący nasz hołd dla tego wybitnego przedstawiciela Kościoła i nieprzemijających wartości, jakie nam pozostawił po sobie na zawsze.

Stanisław Kłys

Ks. Robert Nęcek Adwokat Rzecznik Prasowy Naczelna Rada Adwokacka Archidiecezji Krakowskiej 